\title{
The New Public Management in Sabaneta, Antioquia
}

\author{
Ángel Emilio Muñoz Cardona1,2 \\ ${ }^{1}$ Faculty Public Administration, Superior School Public Administration, Medellin, Colombia \\ ${ }^{2}$ VU University Amsterdam, Amsterdam, Netherlands \\ Email: angel@esap.gov.co
}

Received 25 May 2014; revised 28 June 2014; accepted 5 July 2014

Copyright (C) 2014 by author and Scientific Research Publishing Inc.

This work is licensed under the Creative Commons Attribution International License (CC BY). http://creativecommons.org/licenses/by/4.0/

(c) (i) Open Access

\begin{abstract}
During the decades of the 80s and 90s three international events that marked the history political, social and economic at the beginning of XXI century took place: the fall of the Berlin Wall and Perestroika; Environmental Summit in Rio de Janeiro and the European Union. These historical events deepened new forms of public administration within the developed and developing countries. International events that were and are answer to the demands of citizens by governments more responsive in the management of their needs of participation are: political decisions, environmental protection and economic security. But, how did these three events alter the economic, political and social order in Colombia, and how have these new trends in public management been incorporated into the municipality of Sabaneta, Antioquia? Visualizing the changes of governance since the late 80s and 90s in Colombia, illustration of the good performance achieved by the municipality of Sabaneta in the period from 2003 to 2013, is the subject of this research essay ${ }^{1}$.
\end{abstract}

\section{Keywords}

New Public Management, Transparency of Public Administration, Developmental Plans and Citizen Participation

\section{Introduction}

While Colombia has not lived dictatorships or hyperinflation caused by economic mismanagement; it has faced for over 60 years problems of violence from guerrillas, drug trafficking, drug cartels, paramilitaries and criminal gangs. And while the government has achieved relative control, the institutional public image has been seriously

\footnotetext{
${ }^{1}$ Essay of postdoctoral research about the New Public Management in the municipality of Sabaneta, Antioquia. Investigation performed in the VU University Amsterdam in Netherlands under the direction of honorable Ph.D. Alfons Van Marrewijk.
} 
questioned by political corruption, drug-politics, para-politics and the loss of credibility in justice.

To counter the bad image and preserve the public trust, the Colombian government has followed similar strategies to the ones proposed by Berman (1997): 1) Explain what is intended to benefit the entire community. The government published the development plans and offered the service e-government. 2) Facilitate transparency in the management of public resources. The government invited all community to participate in the elaboration of the participatory budgeting. 3) Accountability. The government showed how to use public resources efficiently. The fulfillment of this goal has required the recruitment and election of officers on merit-profile appropriate to the function of the office — so they can require them personal responsibilities, as mentioned (García, 2007: p. 41).

To account for how the New Public Management has evolved in the municipality of Sabaneta, Antioquia will help understand why it has been listed as the second municipality of Colombia in quality of life and social welfare since 2003 in research reports (Metropolitan Area and DANE, 2004), (CEO, 2005) and (CGA, 2013).

\section{The Fall of the Berlin Wall and the Beginning of Peace Talks}

\subsection{International Context}

Perestroika as a government restructuring program, since 1986, collected the interest groups of the population that was questioned about the future of the nation and the vitality of the communist regime to achieve development (Semenenko, 2013: p. 107). The model of tariff and trade agreements followed by the countries that formed the European Economic Community, EEC showed it achieved greater development than central planning agreements. This recognized the communist model to be the best economic system of social welfare. Much more, when economic growth in reunified Germany was greater (Semenenko, 2013: p. 107); management of public financial resources for infrastructure growth of firms and the expansion of new jobs provided social transformation. The government made the process of integration and unification, maintaining the political, social and economic balance desired (Douglas, 2014: p. 167, 169)2 .

But political transformations and the political will to change would not have been possible if within the agenda of restructuring government had not been present civil action; in other words, the citizen pressure for change. A recent publication by John Gans shows how from 1987 to 1989, through a series of musical concerts scheduled for the German youth, initiatives of social unification and proclamation of the end of communism, "soft power", were gaining sympathy At the first concert of Joe Cocker, says Gans, 80,000 young people attended peacefully together for the same cause. The second concert of Bryan Adams was attended by 120,000 young people and 300,000 attended the concert by Springsteen (Gans, 2013: p. 173).

This dynamic, as some have observed, can be seen in the last days of the Berlin Wall: some officials, aware the status quo could not continue, made choices and policy changes to buy time and defuse dissert, some of which may have worked; but others-such as the travel changes Schabowski mistakenly announced-instead hastened the walls fall (Gans, 2013: p. 175).

The fall of the Berlin Wall and Perestroika marked the end of the communist regime as an alternative model for economic growth in the coming century. This event marked Latin America's demoralization towards communism. It strengthened the idea of democratic governments, and an alternative future economic and social integration; as claimed by Ingo Peters and Elisabeth Bakke in England and Alexandra Guáqueta in Colombia.

One of the most important external factors that influenced southern Europe and Latin America was the domino effect that was generated from the events of the fall of the Berlin Wall. Events that unleashed a series of political changes about the credibility of the communist regimes as it moved the perestroika (Bakke \& Peters, 2011, p.4), (Guáqueta, 2007: p. 426).

\subsection{National Context}

Between 1960 and 1990, the Colombian government worked only with military and police forces in their fight against terrorism guerrilla. And while the guerrillas were not a coherent party ideology, they remained more or less as a common means to establish a new Marxist-socialist government (Von Der, 2011: p. 143). This ideology

\footnotetext{
${ }^{2}$ According to the study by Frank Douglas, after the Berlin Wall fell on 9 November 1989, East Germans began to migrate to the West. It is estimated that between 1989 and 1992, the working population in the West increased by 10\%, this is, 870,000 new workers. From that year, the annual immigration was established between 140,000 and 180,000.
} 
continued until 1982, when some guerrilla groups began to be financed with money from drug trafficking, especially when the USSR began its disintegration and could not help (Guáqueta, 2007: p. 427) with events that contributed to the demobilization of five of seven Colombian guerrilla groups between 1989 and 1994 (Guáqueta, 2007: p. 419). Since the mid-90s, landlords harassed by guerrilla abuses created self-defense groups, which at the end of the decade, were grouped into the United Self-Defense Forces of Colombia. From then until his demobilization in 2003, the self-defenses aided the government in its fight against the guerrilla.

Recent studies at the University of the Andes in Bogotá on the costs of armed conflict and its impact on the closure of manufacturing companies, shows how the intensity of armed conflicts affected the GDP in some more than others to be epicenters of conflict municipalities. It further argues that small firms are more vulnerable to closure (Camacho \& Rodriguez, 2012: p. 96). This is very serious if one considers that over 95\% of Colombian total business are micro and small firms.

But if we consider Colombian history from the economic data or from government decisions without regard to civilians, it is easy to forget half of the history; as society's decision-maker. It is a shadow player, key in achieving the ultimate goals, as we can see from the study of Alexandra Guáqueta:

"In addition, greater access to information regarding the conduct of illegal armed groups on the ground (which has exposed the cruelty of many); the reduced salience of prior "good causes", such as rebellions against dictatorships, due to democratization and the globalization of liberal political ideas; a deeper internalization of human-rights norms and other anti-crime regimes; and the War on Terror that followed the events of September 11, 2001 and the US security policy have shaped the debate and contributed to shunning the issue of political reintegration $(\cdots)$ Other event that had important victories at the local and national levels and obtained the second largest representation in the National Constituent Assembly was the new redaction of Colombia's constitution in 1991, a process that consolidated key democratic reforms and introduced modern liberal ideas on human rights” (Guáqueta, 2007: p. 420, 421).

While international events of the fall of the Berlin Wall and Perestroika fed peace talks in Colombia and even strengthened the social encouragement for the adoption of the constitutional reform in 1991; it has not been possible to achieve peace. During the 90s the paramilitaries, drug cartels and drug trafficking increased the number of crimes against humanity. Thus it increased social disenchantment with politicians signing peace agreements (Chaparro, 2002: 109). It was not possible that democratic actions of the population to support peace initiatives in 1991 served to forgive crimes against humanity (Guáqueta, 2007: p. 425). Political forgiveness granted to the government and guerrilla groups outside law for their demobilization, could not mean that justice lost its moral function of administering justice. Political forgiveness was not equal to social forgiveness (Herrera, 2005: pp. 85-87). National claims were supported by an increasing legislation against international terrorism led by the United States after the events of September 11, 2001 (Von Der, 2011: p. 145). Disappointments in Colombia still persist and are exacerbated by the use of kidnapping as a political strategy of the guerrillas and peace talks have restarted since 2013 without cessation of hostilities.

\subsection{Municipality Context}

The Colombian new public management is based primarily on the principles of Transparency (Law 1712, 2014) and Quality Management (Law 872 of 2003. NTCGP 1000: 2009), which permeate the public administrative nature between the application of the concepts of economy, efficiency and effectiveness in the management of the government organization as well as political instruments of control and improvement of government programs for the selection and monitoring of developmental plans to strengthen citizen participation. In this way, municipalities and political actors strive for total quality in the provision of their services.

In the municipality of Sabaneta, programs aimed at promoting citizen participation are more visible in the missionary duties of the Secretaries of Government and Citizen Development (PEMS, 2004: p. 31) and Private Secretariat (PEMS, 2004: p. 37).

\section{Claims Environmental Summit}

\subsection{International Context}

A proclamation of the Earth Summit in Brazil in 1992 was attended by 1600 representatives of non-governmental organizations; 170 representatives of government; 120 Heads of State and 450,000 visitors. About 100 
press conferences and almost 9000 journalists covered the event (Park, 2001: p. 13). The main outcome of the Summit was reflected in five papers: Two Conventions, Two Declarations of Principles and an Agenda.

The Convention on Climate Change, requested countries commitment to stabilize greenhouse gas emissions and urged to limit the use of fossil fuels, as a direct threat to the economies. (Park, 2001: p. 14). The Convention on Biological Diversity urged on preserving biological life. It proposed that genetic resources are recognized as national property and can only be exploited on the basis of agreements between the signatory States (Park, 2001: p. 14). The Statement of Forest Principles required the protection of forests and the rights of indigenous peoples (Park, 2001: p. 14). The Rio Declaration called on the responsibility of States to avoid damage to the environment of other countries. It recommended to internationalize environmental costs and internalize the principle of economic efficiency: the "polluter pays" (Park, 2001: p. 14).

Agenda 21, has the spirit of international cooperation to integrate countries into policies, programs and projects for environmental development (Park, 2001: p. 16), for the existence of a viable and sustainable society (Park, 2001: p. 28). For example, in order to preserve the environment, it demand of nations to set up agreements for demographic control (Park, 2001: pp. 34-35). Agenda 21 invites civil society to work on preserving the environment. Social movements that eventually will be able to influence the decisions of governments and international trade organizations.

In summary, the 120 countries attending the Earth Summit pledged in four major tasks: the search for alternative energy, biodiversity, the protection of indigenous peoples and control of population growth.

\subsection{National Context}

As for the protection of indigenous peoples, the Colombian government has continued with colonial indigenous property rights, granted by the Spanish Crown and ratified on May 20 of 1820 by President Simon Bolivar. Since 2010, under the decrees 2663 of 1994 and 2164 of 1995 emanating from the law 160 of 1994, the Government seeks to establish the validity and legal continuity of colonial titles from more than 200 years, in order to restructure ${ }^{3}$. According to the National Department of Statistics DANE (2005), in Colombia there are 710 guards and an estimated population of 1,400,000 for the 2013 Indians $^{4}$. Many of them are living outside of their collective land, implying a gradual abandonment of their ethnic customs; some reasons for this are: work, studies, miscegenation or violence. According to the General Controller of the Republic, 27\% of the indigenous people of the Pacific region, for example, do not live in the reservation lands (CGR, 2013).

Under the principles of democratic pluralism, the Colombian Constitution in the article 171 enables indigenous participation in the decisions of Congress: One in House of Representatives and two in the Senate (Avilés, Vanegas, \& Farid, 2012: p. 71). Similarly, in regions with prevailing tax exemptions on land use granted in Article 184 of Law 223 of 1995, (Avilés, Vanegas, \& Farid, 2012: p. 72) the right to ethnic education, according to articles 10 and 68 of the Political Constitution; which encourages the Colombian Indigenous Organization, CIO, working the proposal about Owned Indian Education System, OIES (Avilés, Vanegas, \& Farid, 2012: p. 73).

According to Gredicks, many of the lands occupied by indigenous Colombian tribes are rich in commodities for both the defense industry and manufacturing, which promote violence and legal disorder (Gredicks, 2003: p. 85). Guilds of farmers, for example demand land of indigenous reservations for working by considering it underutilized (Salinas, 2011: p. 373). The firm Ecopetrol, request special permits from the government for oil exploration in indigenous reservations of the Amazon and Putumayo (Salinas, 2011: p. 375). Similarly, the National Government is seeking to reduce poverty and has built roads in indigenous reservations (Salinas, 2011: p. 382).

As for biodiversity. Extensive agricultural production and cattle ranching affect $30 \%$ of Colombian orobioma, losing $10 \%$ of all protected areas (Forero \& Joppa, 2010), that threatens the existence of water resources until 2050. High mountains provide between $90 \%$ and $100 \%$ of freshwater resources for energy production, irrigation and industrial supply in lowland, arid and semi-arid lands (Diaz, Grosjean, \& Graumlich, 2003). In order to preserve biodiversity, the National Government has tightened security in land use (Ruíz et al., 2008: p. 228). And it has maintained relative protection to the virgin forests of the Amazon, among other natural reserves.

As for birth control, demographic studies in Colombia of Gonzales, Houweling, Marmot and Burner (2010)

\footnotetext{
${ }^{3}$ According to Article 184 of Law 223 of 1995: "from the national budget, the nation will rotate annually to municipalities where there are indigenous reserves, amounts to equal what these municipalities no longer collect under certification respective municipal treasurer, on account of the unified property tax, or have not collected by the tax laws surcharges".

${ }^{4}$ http://www.dnp.gov.co/archivos/documentos/DDTS_Ordenamiento_Desarrollo_Territorial/3g11librocapitulo3.PDF. Accessed on May 1, 2014. The Indians, like other Colombians have been victims of violence caused by armed confrontations between the national army and insurgent groups. Threats, massacres, anti-personnel mines and forced recruitment of minors and other young people.
} 
show how levels of education in the female population, and public capital for training aids and grants for planning, reduce population growth. One of the biggest achievements for birth control, was given by the 1412 Law of 2010 which provides a free vasectomy as well, in order to promote the right and civic duty of responsible parenthood. So are, judgments C-355 of 2006 and T-388 of 2009, which induced abortion rights are regulated and legal programs and voluntary interruption of pregnancy are implemented, these include: counseling options, procedures for termination, contraceptive choice and control. Acts that are reflected in the low rates of population growth, according to DANE between 2000 and 2013 has grown at 1.4\% annual average.

On the use and encouragement of alternative energy, recent studies by Ruiz Mendoza, Sheinbaum claim that four of the nation's fastest growing economies in Latin America (Brazil, Colombia, Mexico and Argentina), from 1989 to 2009 have passed specific laws that promote the development of alternative energy, and even with the help of the United Nations have promoted conferences, seminars and international conventions. However, when comparing the achievements after 10 years, it is observed that they are more dependent on the use of fossil fuels that before. And, therefore, the carbon dioxide emissions have increased. Even government prevails in the idea of assisting investors in their profit expectations on future green solutions provided for the welfare of the whole society (Ruíz et al., 2010: pp. 6756-6757).

From there, the director of the Earth Policy Institute, Brown (2009), says in communion with the Agenda 21 of the Earth Summit, that the only way to save the world from environmental damage is the pronouncement of the civil society; it must force governments to strengthen research in the use of alternative energy and implement them; so nations around the world disagree. Countries like Colombia, state that it should be encouraged a higher production of wind, geothermal and solar energy. The fossil energy negatively affects the way society even responds with the same economic efficiency (CEDS, 2010).

\subsection{Municipality Context}

As part of the World Urban Forum Joseph Stiglitz said: Cities are the stage of the most important debates that society has had in its struggle for survival, making them more livable, cleaner, better distributed in their more public spaces, less contaminated by excess greenhouse gases. To do this, cities need to encourage a higher use of public transport, the capacities of their citizens, decent housing and public services. Cities should worry about improving their education system to enable them to survive in a young world economy increasingly changing 5 . Or as say (Diaz, Fargione, Chapin, \& David, 2006: p. 1301) the Human well-being is a human experience that includes the basic materials for a good life, freedom of choice and action, health, good social relationships, a sense of cultural identity, and a sense of security.

The problems of a poorly planned city result in the poorest suffering the most. They are mostly facing problems of lack of sidewalks for mobility, transportation costs and pollution, lack of public parks for family recreation, inequality and segregation that lead to political instability and an economically weak country. Therefore, there is not only a lack of equality in terms of wealth, but also in terms of opportunities as too said Jan Gehl in the chapter one the city as meeting place (Gehl, 2010: pp. 20-30).

In the town of Sabaneta, mission programs of environmental protection, mobility and reducing social inequalities are power Secretaries of Traffic and Transportation, (PEMS, 2004: p. 24); Education and Culture (PEMS, 2004: p. 29); Health and Wellness (PEMS, 2004: p. 26).

\section{The Thrusts of Integration}

\subsection{International Context}

On November 1993 after German reunification and the political union of more 32 political movements of 12 European countries, the Maastricht Treaty gave origin to the European Union. Since then: in 1994, the European Monetary Institute was created. In 1995 the EU is composed of 15 members. In 1999 the European Central Bank is created and the Treaty Amsterdam is celebrated; which sought to consolidate forces to preserve security, justice and freedom for all citizens of the Union (Hoskyns \& Newman, 2000: p. 107). The first of January 1999 the Euro began to circulate as a representative currency of 11 European countries economies.

It was an example of integration that motivated the interest from other countries to form international union blocks as a strategic model of economic growth and development. The search for protected markets between

\footnotetext{
${ }^{5}$ Stiglitz, Joseph (2014), “The city and the inequities,” Keynote, World Urban Forum, Medellin April 14, 2014

http://www.youtube.com/watch?v=BAodXvlGo9Y Website accessed on May 12, 2014.
} 
groups of countries improved urban mobility, macroeconomic management and negotiating power to block the rest of the world. The EU symbolizes social success in terms of labor mobility, cultural integration, economic protection and, above all, political fraternity. But, as Meike Rodekamp says, the voices of civil society contributed and contribute to the objectives of the European Union.

The societal organizations function as so-called "transmission belts of data" between citizens and political institutions by transmitting their members needs and preferences to the decision making centers. More specifically, scholars and practitioners who adhere to the "transmission belt" thesis suggest that civil society organizations have had a role in proving input legitimacy to European Union institutions (Rodekamp, 2014: p. 20).

From there, it does not sound strange the assertion made by Edwards (2009); "Civil society can become the great vehicle of political action”. Where pluralism represents the space of mediation between the spheres of the public and the private in a widening democracy. "This is definitely a good thing, giving a more rigorous political debate and tackles a more analytical approach to civil society as a transformative vehicle”, the action of governments (Edwards, 2009: Preface VI).

\subsection{National Context}

In Colombia, for example, in the late twentieth century a series of momentous changes occurred that had the support of society; first, the law that allowed the expansion of the popular vote in 1988, through Legislative Act No. 1 of 1986, Colombians could elect their Mayors, which involved an extension of the electoral democratic activity, and this derived in more social power. Another of the most important changes of the late twentieth century is the reform of the Colombian Constitution in 1991, which deepened the administrative decentralization both politically and economically, even in the administrative career. The article 130 of the Political Constitution establishes the functions of the National Civil Service Commission, NCSC, with financial and technical autonomy $^{6}$ (Hernández, 2005: pp. 10-11).

Thus, the New Public Management in Colombia is transformed with the constitutional reform of 1991, which opens the door to union political action and responsible civil action. Public administration is strengthened, as stated by Yeatman (1987), because the people with technical training tend to appropriate more change than people of a strictly political, or not technical training, or mandarins. This process has become the seat of the "management” administrative process. That is, a public administration focused on the management and staffing by professional merit in which leadership processes demand projects or lines of implementation (1987: pp. 345-346). This facilitates the efficient use of public resources and improvement in the governmental sector, the culture of doing things right. These acts soothe and improve financial resources demanded by the welfare state (Yeatman, 1987: p. 349).

It is important to analyze the success of the New Public Management by merits "in contrast to the economic and social delays that generates a classic management by bureaucrats, or 'idea guy', managers who are not committed to substantive obligations of public service; as a transparent and equitable administration of government” (Barzelay, 2001: p. 20). It implies a faulty social commitment limited by political favoritism and payments of favor (Barzelay, 2001: p. 31).

Hence the importance of decentralization and citizen participation in the provision of public services; putting in place a governance model based on the relationship State-Citizen with customer orientation as suggested by Premfors (1991: p. 89) serves for the growth of the regional economies; both in creating new jobs and strengthening revenue streams. Decentralization encourages better management of resources with local growth initiatives and local development of social welfare (Premfors, 1991: p. 93), or in an organized society that through civil institutions, as affirmed Benz and Goetz (1996), is pushing the Government for approval and implementation of policies increasing inclusive distribution. A responsible State-Society responsible is capable of reducing the differences between poverty and extreme wealth.

\subsection{Municipality Context}

One of the fundamental duties that distinguishes the managements of the new public administration is seeking to

${ }^{6}$ In Latin America the European Community was origin the new economic models for the globalization and constitutional political reforms in different nations from 1982: Honduras in 1982, Panama and El Salvador in 1983, Guatemala in 1985, Nicaragua in 1987, Brazil in 1988, Colombia in 1991, Peru in 1993, Argentina in 1994, Venezuela in 1999 and more recently Ecuador in 2008 andBolivia in 2009.Similarly from 1990 to 2013 has been promoted twenty educational reforms in 20 Latin-Americans countries. 
meet the real needs of citizens at the lowest cost, through the use of proper mechanisms of competitive markets, such as for example: the mechanism of the reverse auction, the abolition of the state monopoly over the expansion of the supply of companies providing public services and health. Competition mechanisms are intended to promote price controls on final services, expanded coverage and promotion of the highest quality services.

In the town of Sabaneta, efficient use of public resources for development and economic growth according to plan budgets and enforceable land use are missionary duties of the Secretaries of Planning and Development, (PEMS, 2004: p. 34) and Secretariat of Treasure (PEMS, 2004: p. 21).

\section{Conclusions: Sabaneta as an Example of Good Governance}

New Public Management pursues effective administrative decentralization for achieving efficient regional governments in the management of public resources, and scope of the satisfaction of fundamental needs of the population; promoting the use of competitive market mechanisms that allow on the one hand, choosing the best proposal of government, and the other hand by convening citizen participation the monitoring of compliance of campaign commitments; in such a way that bureaucracies are eliminated and full transparency in plans, processes and results is provided, (Muñoz Cardona, 2014). From this perspective, Sabaneta Municipality achieves the incorporation of a New Regional Public Management through the following laws, decrees and resolutions classified following theoretical delineations present in New Public Management.

In accordance to the new institutionalism and the new professional management raised by Christopher Hood (1995), since 2003 the central administration of the municipality of Sabaneta is supported by the appointment of professionals with suitable profile in the management of the 11 Secretaries as suggested by Barzelay (2001) and Yeatman (1987). The current administration (2011-2015), 18\% of staff has MSc studies. 55\% are Specialists and only 27\% have College degree. At the institutional level (see Table 1), citizen participation is increasingly wide when integrating within decisions the sabaneteña youth, representing $17.7 \%$ of the total population and citizen oversight according to Decrees 2350/2003 and 035/2011. Institutions that are relevant to explain the interactions between individuals, which affects selfishness or search for individual preferences as asserted Lapsley and Oldfield (2001).

The new institutionalism in terms of Hood (1991) means the consolidation of the Public Choice own ideas, the theory of Transaction Cost and Agency Theory; clearly visible in municipal agreements that seek to limit the administrative bureaucracy to achieve efficiency in public action through competitive market mechanisms, as

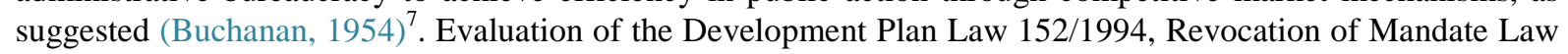
134/1994, Operational Audit Programs Law 87/1993 and Law 1474/2011 (see Table 3) and the laws for Government Procurement Contracts, Law 80/93 and law 1474/2011 (see Table 2).

In terms of the theory of Transaction Cost raised by Hood (1991) requires the existence of perfect information as stated McMaster and Sawkis (1996), this is identify transaction costs associated with the signing of contracts, control of results and achievement of the desired objectives effectively, (Boston, Martin, Pallot, \& Walsh, $1996)^{8}$. In other words, quality control at the lowest cost, as says Al Gore (1993) "Creating a government that Works Better and Costs Less". Sabaneta Municipality implements through mechanisms such as e-government Law 962/2005 (Table 1). And the regulations for the co-financing of projects between the public and private sector, Law 1508/2012 (Table 3); where appear for knowledge all community sabaneteña the contracted firms, firms characteristics, duration and total cost of the contract.

As the agency theory implies the delegation of specific tasks executed by qualified and young persons employed by merit; which institutionalizes the culture of full responsibility, as explained Gimeno $(1997)^{9}$. Facts reflected in the town of Sabaneta in Table 1, through Decree 1510/2013. The exercise of public official by merit prints the work of the public administration the character of management, from this perspective the Secretaries municipality incorporated the Management Plans for stimulus of Sport, Agreement 13/2009, Plan Development Cultural, Agreement 035/2002. Risk Management Plan, Law 1523/2012. Rural Assistance, Decree 364 of 2010. Prevention Strategic Plan on Drug Use, Agreement 31/2002. Programs of Preservation and Conservation Environmental, Agreement 14/2009.

\footnotetext{
${ }^{7}$ Contributions to the theory of Public Choice to New Public Management can be summarized as: $1^{\text {st }}$ : Entering the private sector in the provision of public goods. $2^{\text {nd }}$ : Introduction of market competition mechanisms. $3^{\text {rd }}$ : Reduction of bureaucracy.

${ }^{8}$ The Theory of Transaction Cost defines the New Public Management in terms of: $1^{\text {st }}$ : Organizational Restructuring in relation to the principle of minimal cost. $2^{\text {nd. }}$ : Refining mechanisms of control. $3^{\text {rd }}:$ Motivation for citizen participation.

${ }^{9}$ The Agency theory defines New Public Management in terms of: $1^{\text {st: }}$ Simplification of the hierarchical structure. $2^{\text {nd }}:$ Mechanisms of control according to the profiles of responsibilities. $3^{\text {rd }}$ : Rendición Public Accounts.
} 
Table 1. Promoting citizen participation.

\begin{tabular}{|c|c|}
\hline \multicolumn{2}{c|}{ Municipality de Sabaneta NGP } \\
\hline \multicolumn{1}{c|}{ Transparency and Quality Management } \\
\hline Secretariat Municipal & Programs and Institutional Plans Norms and Main Objective \\
\hline
\end{tabular}

Support Programs for Community Organizations

Training Programs for Democracy.

Program Administrative Procedures

Secretariat of

Government and Citizen Development.

Mission: To promote the citizenship policy of tolerance, coexistence, peace, participation and civic culture.

Social Inclusion Programs

Programs for the Control
Organizational office and support a community agencies. Providing advice and support a different social organizations in municipality topics: legal, accounting and organizational psychology. Law 473 of 2002 and its implementing, decree 2350 of 2003.

Municipal government child: semillero training children and youth in your rights as citizens. Teaching them to know how does the public sector. Municipal agreement n. 24 september 2009. Sabaneta development plan, law 743 of 2002.

Decree 19 of 2012. Objective: delete or amend the paperwork, procedures and unnecessary regulations in the public administration, in order to facilitate the activity of natural and legal persons to the authorities, to the efficiency and effectiveness of these and implement constitutional principles that governing.

Decree 230 del 2003 is created the office of youth. Agreement 07 del 2010 is created and regulation the municipality council of youth. decree 035 of 2011 date fixing for the election of the municipality council of youth. Decree 115 del 2003, is created the municipality council of disability care. of Violence

Attention displaced or victims by armed conflict. Law 361 of 1997. Law 1145 of 2007. Municipal development plan, agreement 005/2007.

Programs to Control Prostitution No reports information

Formation Programs for Young Offenders

Programs of Control to Proliferation Misdemeanors

Programs Administrative Transparency

Bidding and Purchasing Programs

Programs of Labor procurement Merit

Program for Prevention and Control of the Public Corruption

\section{Participatory Budget Programs for the 24 neighborhoods and 6 locations}

Plan of Government on Line Democracy in Line
No reports information

Strengthening and modernization program comprehensive security system. 37 security cameras installed in different areas of city sidewalks and crime prevention. Prohibition of passenger man in moto between 9:00 a.m. to 11:00 p.m. Throughout, with doing this measure reducing homicide, street bank and theft. protecting program at youths, for reduce the risk of consum alcohol and drugs; perform operational for children age detect violating the standard established in decree 141 of 2009.

Decree 1599 of 2005. Standard internal control model, meci 1000:2005 seeks to guide institutions towards meeting their objectives and their contribution to the essential purposes of the state. Strategic control subsystem: orients the entity to compliance vision, mission, objectives, principles, goals and policies. Control subsystem management: plans, programs, processes, activities, procedures, resources, and media. Control subsystem evaluation evaluates the results permanent.

Law 80 of 1993, law 1150 of 2007 and decree 1510 of 2013. For the efficiency and transparency in the hiring with public resources. In terms of: publicity, equality, transparency and objective selection.

The city complies with the provisions of the national decree 1510 of 2013. Decree regulating the legal provisions contained in the general contracting of public administration, and other laws applicable to government contracts.

Law 1474 of 2011. By which established rules strengthen oriented preventive mechanisms, research and punishment of acts of corruption and effectiveness of control of public administration.

No reports information

Government online. Law 962 of 2005 and decree regulatory 1150 "strategy of territorial government online gel-t".

Note: Source: Secretaries from Sabaneta. AES (2008). Development Plan (2012-2015) and Management Report, CGA (2013). 
Table 2. Environmental protection, mobility and reducing social inequalities.

\begin{tabular}{ccc}
\hline \multicolumn{2}{c|}{ Municipality de Sabaneta NGP } \\
\hline \multicolumn{1}{c}{ Transparency and Quality Management } \\
\hline Secretariat Municipal & Programs and Institutional Plans & Norms and Main Objective \\
\hline
\end{tabular}

Traffic Restriction Program No reports information

Secretariat of Traffic and Transportation.

Mission: Thought planning, regulation and control of traffic and transport activities, contribute to the social and economic development, providing good services to the municipality mobility.
Parking Control in Urban Areas

Pedestrian Trails Plan

Licensing Regulatory Programs

Driver Education Programs and Signage

Programs for the promotion of Entrepreneurship

Programs for Promoting Reading

\section{Secretariat Education} and Culture.

Mission: Advise, accompany, facilitate and Lead plans, programs, projects and actions aimed at the provision of comprehensive services with efficiency and quality.

The study of quality of life Educational plans for (CEO 2005) says: Sabaneta Population Growth Control municipality have the education levels highest average of metropolitan area in all age ranges of population.
Rationalising the use of the street. Improve the mobility of vehicles, ensuring the accessibility to user, comfort and safety in the street. Law 769 of 2002, municipal decree 055 of 2013.

No reports information

No reports information

Increase the park automotive in the municipality of Sabaneta. Law 769 2002, municipal agreement 0182012 and resolution department of transportation 12379 of 2012.

No reports information

Business support. The south chamber of commerce and the municipality of Sabaneta to qualify and advice in assembly and enterprise creation. Agreement 946 July 16, 2013. Business plan development for entrepreneurs who want to land your business idea and are ready to formalize. In support agreement art 355 of political constitution. Document 777 of 1992.

Strengthening libraries. Put at the service of the education sector of information technology and communications. National plan for reading and writing (nprw) and guidelines coming from the ministry of national education (mne).

Construction of citizenship. Promoting social policies that contribute to the construction of citizenship. According to guidelines of the international association of educating cities (iaec). Decree 185 of April 20, 2009.

Best secundary students. Facilitating access and retention in higher education in formal educational institutions. Norms: municipal agreement $013 / 2012$, by which are compiled and modify municipal agreements 08/2008, 05/2009 and 017/2009.

\section{No reports information}

Decree 109 del 2010, regulating the advisory board of gender created by agreement of 2009 021. Decree 049 of 2011 through which is created the municipal board to end violence against women. Law 248 of 1995, which by approving the american convention on the prevention, punishment and ending violence against women. Law 984 del 2005 elimination of all forms of discrimination against women. Alternative job training or income generation, to contribute to the prevention of violence and forms of discrimination against women. Classification according to the law given by 12572008.

Programs for the Promotion of Culture. 388 training courses in the six arts areas: music, dance, theater, visual arts, street art and crafts with 3120 registered users in age from 3 to 80 years old
Agreement 005/2007 creation traveling music program. Agreement 005/1881 creation of the house of culture. Agreement 039/1993 school building art education. Agreement 015/2012 school building music alberto velasquez mauricio correa. Agreement 01/2009 municipal building of historic stock. Agreement 013/1998 modified by agreement 07/2012 creation of the city council of culture. Agreement 035/2002 adoption plan development cultural council of Sabaneta 2002-2012. 


\section{Continued}

Agreement 031 December 11, 2008 through which adopts public policy. A community without malnutrition. Bond supply nutritional support

Nutrition Programs for families of high economic vulnerability. Supply, delivery and preparation of food for portions food program for schools school officials and kindergarten.

Programs Community Homes

Agreement 013 of 1994 through which subsidize community household in public services of family welfare. decree 050 of 2001 . Mothers support community with payment of $30 \%$ of public services. Decree 013 of 2013 by which establishes a monetary stimulus for community mothers of $30 \%$ of current legal minimum wage.

Programs of comprehensive public Law 1122 of 2007 law state responsibility to ensure the attention in health (promotion and prevention). public health. Agreement September 2005014 promote a comprehensive Strengthening the information program of the population under 7 years where he gives priority to medical system. Use of georeferencing software that allows actualization of health

\section{Secretariat
Wellness.}

Mission: Ensure the proper functioning of social needs, and provides the security in Health, through needs, and provides the
actions Public Health, Basic Care Plan, Monitoring and Control, guaranteeing health care coverage to the poor and vulnerable.

Programs Phytosanitary Treatment Programs and Waste Management

Report the quality of life (CEO 2005) says: the 10 cities metropolitan area has Sabaneta better housing both ${ }^{\text {Programs Against Drug }}$ urban and rural. Major use of appliances per inhabitant. Program for the Promotion of Optimal health services. Sports.

Best waste treatment system The municipality has 13 sports in rural areas. vaccination. Agreement 012 May 30, 2008 through which are established few days prevention, detection, care and decrease of death for breast cancer, cervical and women in prostate in men. Agreement 04 June 2 2010 for which establishes the days of health positions as a contribution to the culture of prevention.

In accordance with the law 9 of 1979, sanitary code. Decree 1311 of 2002, decree 2676 of 2000. Talk about the legislation and treatment plant protection product. Environmental infringers sanction a grooming standards, cleaning and waste collection. Agreement 28 of 2009 and the decree 327 of 2010, where regulations environmental sanction. Decree 2981 of 2013 is regulates the provision of public grooming.

Agreement 031 December 10 of 2002 through which adopting the strategic plan 2002-2010 drug prevention.

The political constitution elevated to a fundamental right of sport and recreation. Subsequently, by legislative act 2 of 2000 is recognized "sport and recreation" as part of public social spending in the pursuit of well-being and improving the quality of life of the population. Decree law 4183 of 2011, the agreement 13, 2009 of the board of coldeportes creates the municipal sports ten year plan. in its 15 square miles (AES, 2008)

Program for Older Adults. $15 \%$ of the population is older and are covered $100 \%$

Agreement 038 of 1993 creates the center of comprehensive care to the elderly. Agreement 12 of 2009 regulates the benefits are protected, promote and defend the rights of the elderly.

Agreement 014 of 2005 is created the municipal systen of welfare for family. Decree 044 del 2007, regulating the municipal welfare system for family. Agreement 06 of 2010, are acknowledge the economic and cultural rights of women and man head of household. Decree 050 of 2001 establishing the municipality council for social policy. Decree 141 of 2009 through which sought preventive protection of the rights of children and teens. National family day. Law 1361 of 2009.

Note: Source: Secretaries from Sabaneta. AES (2008). Development Plan (2012-2015) and Management Report, CGA (2013).

The municipality of Sabaneta not promote participatory budget within the community as established by standards, Law 152/1994, Law 388/1997 and Law 28/2008; but if it complies, in an exemplary manner, with the development plan according to the results of monitoring and evaluation carried out in accordance with the law for indebtedness and investment, Decree 1599/2005 (see Table 1). According to the report, the town of Sabaneta has supported financial liquidity in own resources, that ensure and support the running costs and investment programs. That is, the municipality of Sabaneta little needs of the transfers of the Nation for function. As a rule, transfers are $17 \%$ of the total income of the municipality, which encourages the pursuit of administrative efficiency (GGA, 2013).

The achievement of security and peaceful coexistence in Sabaneta Municipality lies not only in the existing regulations, also in civic education for the knowledge of the public as stable Agreement 24/2009 for the formation of democracy (Table 1). Dissemination Citizens Securities, Decree 185/2009 (Table 3). Citizens aware of their choice for the good of the whole community (Muñoz Cardona, 2014). 
Table 3. Efficient use of public resources for development and economic growth.

\begin{tabular}{|c|c|c|}
\hline & Municipality de Sabaneta NGP \\
\hline & Transparency and Quality Management \\
\hline Secretariat Municipal & $\begin{array}{c}\text { Programs and } \\
\text { Institutional Plans }\end{array}$ & Norms and Main Objective \\
\hline
\end{tabular}

Plan Infrastructure Urban.

In accordance with the law 388 of 1997 and by agreement 022 of 2009. Adopting the developing urban infraestructure. At present come on following urban infrastructure projects: decree 185 of 2012 for 15 years. Decree 153 of 2012 for 10 years. Decree 065 of 2012 for 10 years. Decree 060 of for 10 years. Decree 242 of 2011 for 15 years. Decree 076 of 2005 for 10 years. Decree 0342 of 2010 for 15 years.

Urban Landscape.

Urban citizen enjoys 2.17

square meters per

inhabitant green zone

\section{Basic Plan Land Use}

Management Plan for Public spaces

Risk Management Plan

\section{Secretariat of Planning \\ and Development. Environmental \\ Mission: Ensure \\ compliance with the \\ Development Plan \\ and Land Use Plan, \\ lead programs and \\ projects with \\ community \\ participation, \\ provide statistical, \\ economic, and \\ population for the \\ optimal use of \\ information resources. Program}

\section{Control Plan for Urban \\ Construction \\ Control Plan for Urban \\ Growth}

Programs Attention Poverty

Programs for Employment Promotion

Housing Improvement Plan

Project Co-financing Programs
Increase public green spaces, improvement landscaping, enjoy environmental construction of linear, natural parks and border; actions that contribute to wellness and visual environment and improve sanitation and pedestrian safety for the conduct of recreation and culture. Restored to a public area of 70,000 square meters and added in new 4500 square meters new. Agreement June 05/2012. Restoration of 12,200 m² public green space with ornamental planting maintenance and adjustments of existing green areas. Agreement June 05/2012.

No updates reported for the last 10 years

No report information

Program for identification and monitoring of danger zones. Early alert system implementation, easi. Installation of five rain gauges located in strategic areas which used to determine the amount of water abrupt and disaster prevention. Risk management plan, law 1523 of 2012.

Integral management plan of solid waste. Municipal resolution 538 of 2005. ludoteca environmental "libelulas" 06 agreement of 05 of 2012. Agreement 14 of 2009 fixing the guidelines of public management policy and management for rational use of water. In accordance with the law 1450 of 2011 in the article 210, for the conservation water resources, the municipality bought 203, 783 acres.

Provision of services to support activities municipal management performing as secretary of environment technical maintenance in public spaces and green areas to carry out work environmental education in the municipality of Sabaneta. Law 1150 of 2007.

No continuity programs reports

Decree 364 of 2010. Rural direct assistance technical general plan. Through which seeks to strengthen the competitive advantage of the sector, road and commercial infrastructure that has the municipality.

No reported information

No reported information

Support for people with high vulnerability socioeconomically in kind or money, providing to improving their conditions of life. Agreement 06 of 2012.

General job skills and training for work and human development. In accounting and finance, marketing and executive secretariat with accompanying ceoget ministry of education, to expand the scope of the system of quality management standards in ntc 5555 "sgc for training institutions to work" and ntc 5581 "training programs for the job".

Fund for the promotion of social interest housing and urban reform. Agreement 006 del 2006, for the improvement of living. Agreement 018 of 2006, granting subsidy. Agreement 011 of 2001, decrease rate financing. Agreement 002 of 2009 selection and award of 500 housing of priority interest. Resolution 001 of 2013 by which is set the urban reform, (bsih).

Law 1508 of 2012, decree 1467 of 2012. Whereby is established the legal regime of the public private partnership, are dictate organic standards budget and other provisions. 


\section{Assessment of} Development Plans

Secretariat of Treasure.

Revocation of mandate

Mission: Achieving the objectives of the Public Administration as preceptor and investment Audit Work Programs of fiscal resources through the collection of resources, effectiveness of spending, correct direction of public debt and its proper accounting General Plan of Public Accounting
Law 152 of 1994. to ensure the progressive consolidation general welfare and improving the quality of life of people in the preparation, adoption and implementation of development plans of the nation and territorial entities they have as a criterion special in the territorial distribution of public spending the number of people with unsatisfied basic needs, the population and fiscal and administrative efficiency, and public social spending has priority over other assignment.

The revocation mandate is a mechanism for citizen participation provisions of law 134 of 1994. Instrument to exercise control and ensure effective acts of state. The revocation of the mandate is a political right, through which citizens can terminate the mandate conferred on it by a governor or a mayor.

Determine the effectiveness with which are achieved the pre-established objectives and the efficiency and economy to use and gets the resources, in order to suggest recommendations that will improve the future management of an entity. Law 87 of 1993. 14742011 act, meci 1000.

The general plan public accounting, law 617 of 2000 sets limits the expenditure of the municipalities according to their category. Instrument legal financial with purposes rationalise spending and tax recovery.

Regulatory Plan Municipal Rules of ability to pay municipality; development plans, embargo of income from Indebtedness territorial entities 364 of the constitution. Law 358 of 1997 and decree 2805 of 2009 on investment of state resources order territorial entities.

Law 909 of 2005. Decree 2770 of 2005. Institutional improvement plan includes recommendations and analysis generated in the development of the components of Public Management Model. internal auditing, independent evaluation and comments organ fiscal control.

Continuous improvement The entity must structure the improvement plan to be get ahead in a given period, adjusted with its mission, vision, corporate objectives, functions and resources available.

Note: Source: Secretaries from Sabaneta. AES (2008). Development Plan (2012-2015) and Management Report, CGA (2013).

From this perspective Sabaneta Municipality achieves its contribution to social welfare function, quality of life and, ultimately, to the happiness of the people. Since 2003, Sabaneta is recognized as the second best municipality in quality of life between 1102 Colombian municipalities. Acts that are reflected in the fulfillment of programs such as, (see Table 2): Quality of Life for the Elderly, Agreement 038/1993. Protection of gender equality, Law 1257/2008, Agreement 21/2009, Decree 49/2011. Protection of children and family, Agreement 31/2008, Agreement 13/1994, Agreement 44/2007, Agreement 14/2005 and Decree 050/2001. And strengthening of knowledge, through the granting of University Scholarships at the best graduates, Agreement 13/2012 and nutrition programs, Agreement 031/2008.

For the general community Sabaneta Municipality offers a health coverage above $95 \%$ through Integrated Programs Public Health Agreement 14/2005, Law 1122/2007 (Table 2). In aid to the poorest families (see Table 3): Plan of Improvement Housing, Agreement 18/2006 and Resolution 01/2013. Programs strengthen and modernize the integrated system of security for the control of minor offenses and ensuring a peaceful life and peaceful Decree 141/2009. Landscaping and beautification Urban Development Plan Agreement 6/2012.

Negative aspects to consider because they are unbalanced factor of quality of life in the town of Sabaneta and success of the NPM in the short-medium term, originate through the annual average population growth in the last 10 years of 2.29\%; it representing an urban density of 4980 persons per square kilometer, according to data obtained and projected (AES, 2008), (PEMS, 2004) (Decree 364/2010), (CEO, 2005) and the report (CGA, 2013).

The Secretariat more reflecting the lack of control in the urban growth is the Traffic and Transportation. This has become urban culture, the parking of private vehicles on public roads, without corrective action; making it difficult to free mobility and causing inescapable accident. Acts that are even more serious with the Municipal Agreement 018/2012 and Resolution 12379/2012 to increase the number of vehicles in the town of Sabaneta (see Table 2). The report of the CEO of the University of Antioquia (2005) states that Sabaneta has the highest average use of private vehicles in whole Metropolitan Area.

The lack of planning and control urban growth in Sabaneta is reflected in the lack of clarity and Plan Update Urban Construction, Plan Basic of Land Use and Management Plan Public Space. Management Programs be- 
long to the Secretariat of Planning and Development (Table 3). Absence management threatens the habitat quality, especially when Sabaneta has the highest levels of urban and rural overcrowding of all Metropolitan Area (CEO, 2005).

The municipality of Sabaneta lacks public policies aimed at recycling of waste management in the 24 neighborhoods of the urban area. Absence of public policies threatens the preservation of the two main water sources that cross the municipality with its 30 effluents, since there is a high population growth and urban construction (see Table 3). For the government of municipality of Sabaneta the human well-being of the majority of their citizens is based more or less directly on the sustained delivery of fundamental ecosystem services, such as the production of food, shelter and the regulation of the quality and quantity of water supply, the control of natural hazards; as say the researches (Diaz, Fargione, Chapin, \& David, 2006: p. 1301) and the Development Plan of municipality (2012-2015).

Another downside is the discontinuity of institutional sexual education programs to control population growth and protecting the quality of life of adolescents (Table 1). Similarly, it is the lack of training programs for young offenders. Impact possibly supported by levels of income and education of parents of adolescents, both urban and rural areas (CEO, 2005).

Finally, another problem that easily generates an unchecked population growth, other than the market price of the land is the inflation of supply; causing deindustrialization, loss of industrial base, increases in unemployment among young people and eventually deteriorating the current revenues of the municipality for investment and spending. Similarly, Sabaneta town doesn't make great efforts in entrepreneurship programs, to open the doors by new future alternatives of employment for youth (Table 2) preserving the quality of life population and the financial independence municipality of the national transfers.

\section{References}

AES, Anuario Estadístico de Sabaneta (2008). Secretaría de Planeación y Desarrollo Territorial, Información Estadística Básica, Municipio de Sabaneta.

Área Metropolitana y Departamento Nacional de Estadísticas, DANE (2004). Plan Estratégico del Municipio de Sabaneta. Colombia: Dirección de Difusión, Mercadeo y Cultura Estadística del DANE.

Avilés, W., Vanegas, B., \& Farid, S. (2012). Indigenous Resistance and the Law. Latin American Perspectives: Sage, 39, 61-77.

Bakke, E., \& Peters, I. (2011). 20 Years Since the Fall of the Berlin Wall: Transitions, State Break-up and Democratic Politics in Central Europe and Germany. Cambridge: Intersentia Ltd.

Barzelay, M. (2001). The New Public Management: Improving Research and Policy Dialogue. Oakland: University of California Press.

Benz, A., \& Klaus, G. (1996). The German Public Sector: National Priorities and the International Reform Agenda. In A. Benz, \& K. Goetz (Compilations.), A New German Public Sector? (pp. 1-26). Dartmouth: Reform, Adaptation and Stability, Aldershot (England).

Berman, E. M. (1997). Dealing with Cynical Citizens. Public Administration Review, 57, 105-112.

Boston, J., Martin, J., Pallot, J., \& Walsh, P. (1996). The New Zealand Model. Oxford: Oxford University Press.

Brown, L. R. (2009). Plan B 4.0: Mobilizing to save the Civilization. New York: Earth Policy institute, W. W. Norton \& Company.

Buchanan, J. M. (1954). Individual Choice in Voting and the Market. Journal of Political Economy, 62, 334-343.

Camacho, A., \& Rodriguez, C. (2012). Firm Exit and Armed Conflict in Colombia. Journal of Conflict Resolution, 57, 89-116.

CEDS, Centro de Estudios para el Desarrollo Sostenible (2010). Cambio Climático. Mercados de carbono, Instrumentos Económicos y Ayuda al Desarrollo. Bogotá: Universidad de los Andes.

CEO, Centro de Estudios de Opinión (2005). Informe Final de trabajo de campo Calidad de Vida Área Metropolitana. Medellín: Universidad de Antioquia, Facultad de Ciencias y Humanas, Estudios de Opinión.

CGA, Contraloría General de Antioquia (2013). Informe de Rendición de Cuentas, Municipio de Sabaneta, Audiencia Pública.

CGR, Contraloría General de la República (2013). Informe Especial Seguimiento Recursos del sistema General de Participaciones Asignación Especial para Resguardos Indígenas. Región Pacífica, Informe número 4.

Chaparro, A. A. (2002). Cultura Política y Perdón. Bogotá: Universidad del Rosario. 
DANE, Departamento Administrativo Nacional de Estadísticas (2005). Censo General, Conciliación demográfica, Bogotá, Mayo 22 de 2005.

Development Plan (2012-2015). Sabaneta una construcción social. Sabaneta Antioquia: Alcaldía Municipal. http://sabaneta.areadigital.gov.co/Documents/PlanDllo2012-2015.pdf

Diaz, H., Grosjean, M., \& Graumlich, L. (2003). Climate Variability and Change in High Elevations Regions: Past, Present and Future. In H. F. Diaz (Ed.), Climate Variability and Change (pp. 5-33). Switzerland: Kluwer Academic Publishers.

Diaz, S., Fargione, J., Chapin III, S., \& Tilman, D. (2006). Biodiversity Loss Threatens Human Well-Being. PLoS Biology, 4, 1300-1305. http://dx.doi.org/10.1371/journal.pbio.0040277

Douglas, H. F. (2014). Governance Institutions and Adaptation Costs: Evidence from the fall of the Berlin Wall. Management Science, 60, 166-187. http://dx.doi.org/10.1287/mnsc.2013.1736

Edwards, M. (2009). Civil Society (2nd ed.). Cambridge: Polity Press.

Forero-Medina, G., \& Joppa, L. (2010). Representation of Global and National Conservation Priorities by Colombian’s Protected Area Network. PLoS ONE, 5, e13210.

Gans, J. A. (2013). Did Bruce Springsteen Win the Cold War? Survival: Global Politics and Strategy, 55, 169-178.

García, S. I. M. (2007). La nueva gestión pública: Evolución y tendencias. Universidad Salamanca, Revista Presupuesto y Gasto Público, No. 47, 37-64.

Gehl, J. (2010). Cities for People. Washington DC: Island Press.

Gimeno, R. A. (1997). La descentralización de la gestión pública. Implicaciones contables. Actualidad Financiera, monográfico $2^{\circ}$ trimestre, 44-50.

Gonzales, C., Houwelin, T. A. J., Marmot, M. G., \& Burner, E. J. (2010). Comparison of Physical, Public and Human Assets as Determinants of Socioeconomic Inequalities in Contraceptive Use in Colombia Moving Beyond the Household Wealth Index. International Journal for Equity in Health, 9, 10.

Gore, Al. (1993). From Red Tape to Results. Creating a Government that Works Better \& Costs Less. Report of the National Performance Review, Washington DC: U.S. Government Print Office.

Gredicks, A. L. (2003). Resource Wars against Native peoples in Colombia. Capitalism Native Socialism, 14, 85-111. http://dx.doi.org/10.1080/10455750308565525

Guáqueta, A. (2007). The Way Back in: Reintegrating Illegal Armed Groups in Colombia Then and Now. Conflict, Security and Development, 7, 417-456.

Hernández, P. A. (2005). La provisión de empleos de Carrera en Colombia: Lineamientos de un nuevo modelo de gestión de personal en el sector público. Bogotá, X Congreso Internacional del CLAD, sobre la reforma del Estado y de la administración pública, Santiago de Chile, 18 al 21 de octubre de 2005.

Herrera, J. C. J. (2005). Reconciliación y Justicia Transicional: Opciones de Justicia, Verdad, Reparación y Perdón. No. 18, Bogotá: Papel Político, 79-112.

Hood, C. C. (1991). A Public Management for All Seasons? Public Administration, 69, 3-19.

Hoskyns, C., \& Newman, M. (2000). Democratizing the European Union. Manchester: Manchester University Press.

Lapsley, I., \& Oldfield, R. (2001). Transforming the Public Sector: Management Consultants as Agents of Change. European Accounting Review, 10, 523-543. http://dx.doi.org/10.1080/713764628

McMaster, R., \& Sawkis, J. W. (1996). The Contract State, Trust Distortion and Efficiency. Review of Social Economy, 54, 145-167. http://dx.doi.org/10.1080/00346769600000034

Muñoz Cardona, Á. E. (2014). The Social Game between the Vote and the Democracy. Open Journal in Political Science, 4 , 89-100. http://dx.doi.org/10.4236/ojps.2014.43010

Park, C. C. (2001). The Environment: Principles and Applications (2nd ed.). London: Routledge.

PEMS, Plan Estadístico del Municipio de Sabaneta (2004). Bogotá-Colombia. Dirección de Regulación, Planeación, Estandarización y Normalización, DIRPEN-DANE.

Premfors, R. (1991). The Swedish Model and Public Sector Reform. West European Politics, 14, 83-95.

Rodekamp, M. (2014). Their Members Voice: Civil Society Organizations in the European Union. Berlin: Springer. http://dx.doi.org/10.1007/978-3-658-02213-6

Ruíz, D., Moreno, H. A., Gutiérrez, M. E., \& Zapata, P. A. (2008). Changing Climate and Endangered High Mountain Ecosystems in Colombia. Science of the Environment, 398, 122-132.

Ruíz, J., Mendoza, B., \& Sheinbaum, P. C. (2010). Electricity Sector Reforms in Four Latin-America Countries and Their Impact on Carbon Dioxide Emissions and Removable Energy. Energy Police, 38, 6755-6766. 
Salinas, C. (2011). Colonization and Resistance: Oil, War, and the Ongoing Attempt to Destroy the Kofan People of Colombia. South Atlantic Quarter, 110, 363-383. http://dx.doi.org/10.1215/00382876-1162498

Semenenko, I. (2013). Perspectives on European Politics and Society. Russia: World Economy and International Relations (IMEMO), Russian Academy of Sciences and National Research, University Higher School of Economics.

Von Der, C. (2011). The Conflict in Colombia and the Relationship between Humanitarian Low and Human Rights Law in Practice: Analyses of the New Operational law of the Colombian Armed Forces. Journal of Conflict and Security Law, 16, 141-164. http://dx.doi.org/10.1093/jcsl/krr004

Yeatman, A. (1987). The Concept of Public Management and the Australian State in the 1980s. Australian Journal of Public Administration, 46, 339-353. 
Scientific Research Publishing (SCIRP) is one of the largest Open Access journal publishers. It is currently publishing more than 200 open access, online, peer-reviewed journals covering a wide range of academic disciplines. SCIRP serves the worldwide academic communities and contributes to the progress and application of science with its publication.

Other selected journals from SCIRP are listed as below. Submit your manuscript to us via either submit@scirp.org or Online Submission Portal.
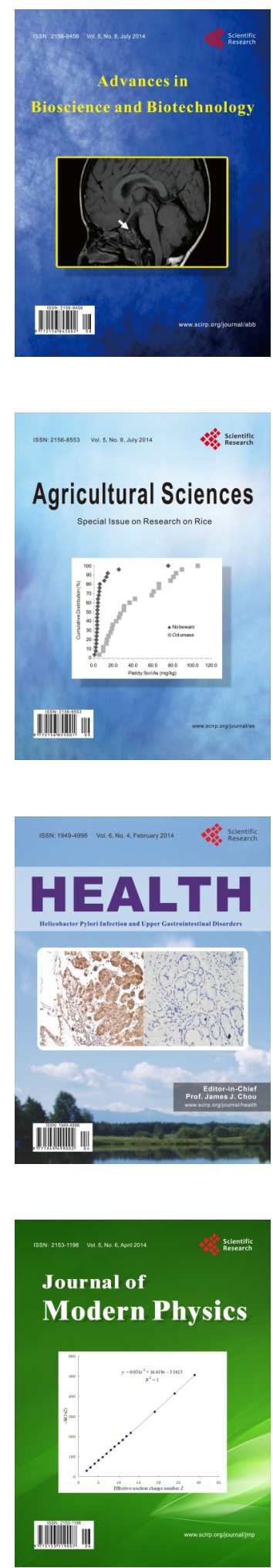
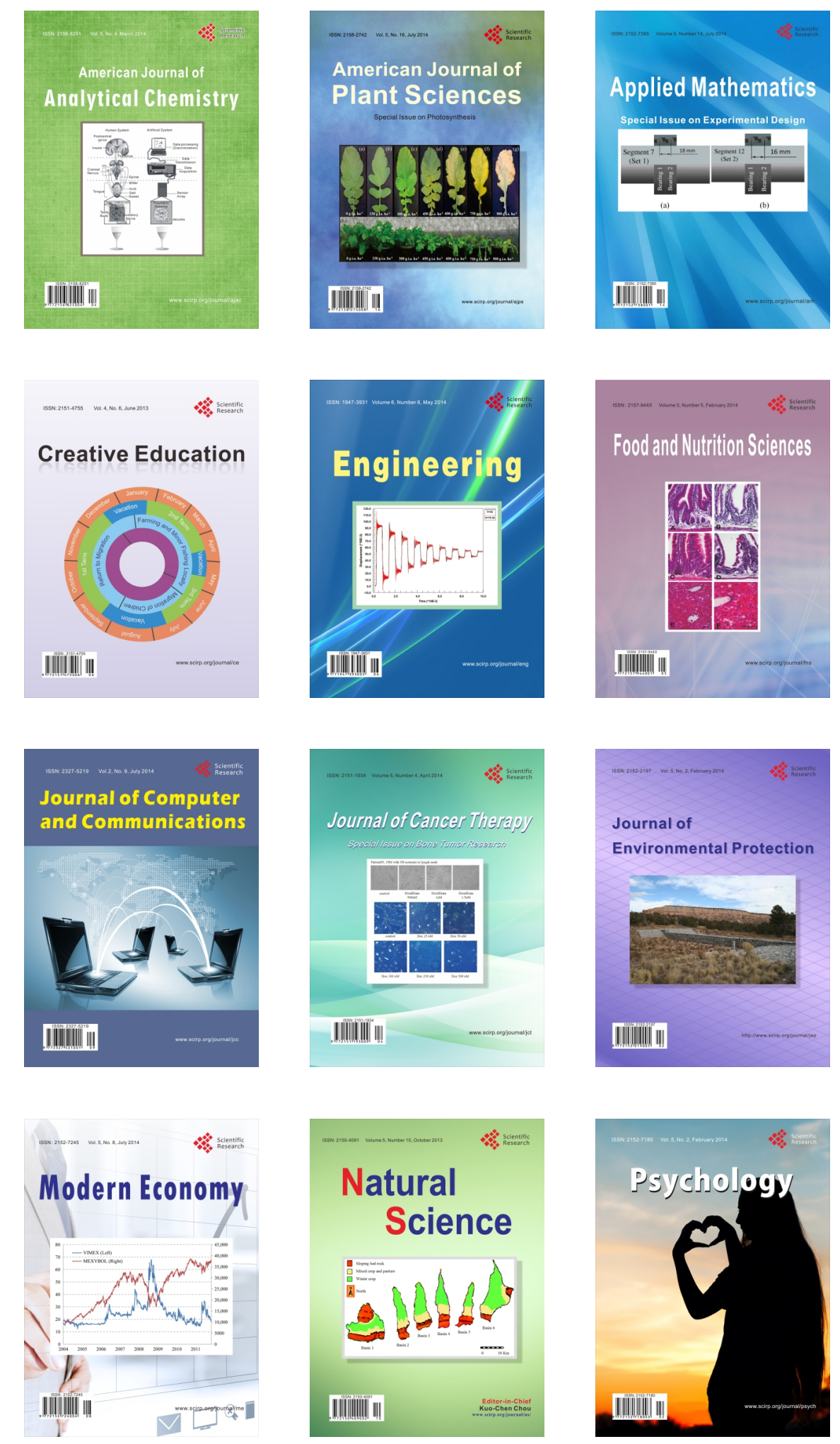